\title{
How to transform creative ideas into creative products: learning from the success of batik fractal
}

\author{
Horas Djulius \\ Faculty of Economics, \\ Pasundan University, \\ Bandung 40116, Indonesia \\ Email: horasdjulius@unpas.ac.id
}

\begin{abstract}
The existence of the creative industry is one of the characteristics of the knowledge economy where its form may vary between countries. For many developing countries as well as Indonesia, creative industry plays important roles. Bandung, known as emerging creative city, has many factors to promote the creative industry. Many creative ideas that come out of the talented young people can be transformed into creative products such as batik fractal. This research aims to study the batik fractal's road map that has successfully transformed the creative ideas by utilising enabling factors that already exist. The method used was qualitative research method through in depth interview and triangulation of what was presented by the founder of the batik fractal. The results showed that at every phase of its development, the founders were able to integrate internal and external supporting factors to continue to develop to the next stage.
\end{abstract}

Keywords: creative ideas; knowledge sharing; batik fractal; creative product; innovative product; creative industry; creative city.

Reference to this paper should be made as follows: Djulius, H. (2017) 'How to transform creative ideas into creative products: learning from the success of batik fractal', Int. J. Business and Globalisation, Vol. 19, No. 2, pp.183-190.

Biographical notes: Horas Djulius is an Associate Professor of Faculty Economics at the Pasundan University. He teaches econometrics, research methodology and managerial economics in both undergraduate and post-graduate programs. His research interest focusing on knowledge spillover has been started from his PhD dissertation in 2005. Currently, he is continuing such research topic to the intersection between macro and micro perspective on knowledge economy and innovation.

This paper is a revised and expanded version of a paper entitled 'How to transform creative ideas into creative products: learn from the success of batik fractal' presented at the SIBR-UniKL 2016 Conference, Kuala Lumpur, 12-13 February 2016.

\section{Introduction}

Creative industries link creative ideas with creative products (Lazzeretti et al., 2009). The industry is usually located in urban areas (Turok, 2003) and establishes an industrial cluster naturally (Bayliss, 2007). Therefore, many countries pay particular attention to the 
development of creative industries in the main cities in their countries. This particular attention was given because of the awareness that the determinants of economic growth in the future will be characterised by the knowledge-based economy. The knowledge-based economy is an economy that the central factor of economic growth determined by people who deploy and use new technology (Melnikas, 2010). In Indonesia, one of the cities that meet this definition is Bandung City. This circumstance is reinforced by UNESCO recognition that Bandung is one of 47 cities in the world that joined into the creative cities network (UNESCO Press, 2015).

One of the products of creative industries in Bandung is batik fractal. Currently, batik fractal developed by communities in Dago Pojok area in Bandung. This community has a goal to create public engagement especially for those who lived in densely populated area by using technology to produce creative products (Margried, 2015). The development of batik fractal up into its condition today begins from the emergence of creative ideas from creative class in the city of Bandung. Their appearance can not be separated from the many universities in this city as well as a variety of other supporting factors.

By studying the roadmap that has been undertaken by the batik fractal, many young talented people and governments in developing countries can share their role in realising the creative economy which gives a lot of value added to the community. This happens because of two reasons. Firstly, a lot of creative industries in developing countries emerge spontaneously, so there is not enough time for them to plan their development, right from the beginning. Secondly, because of the scale of their business are mostly micro and small, so it takes the role of government to become an enabler party which supports them through regulations and infrastructures.

\section{Literature review}

Creative idea is the imagination phase of creativity process which in turn can change new ideas into reality. Creative product is the fruit of the creative industry which its products contains symbolic cultural values (Simatupang et al., 2008). Currently, the creative industries have become the leading sectors of intellectual property based in various countries. Based on the study conducted by Holden (Carr, 2009), an understanding of the creative industries oriented toward two things, i.e., the creative capacity of individuals and categorisation of the types of creative industries. Thus, as stated by Lazzeretti et al. (2009) creative industries enabling creative ideas that emerged from individuals, processing to be a creative product.

According to Florida (2003), the growth of creative industries supported by 3T, i.e., talent, technology and tolerance. Talent is the existence of people who produce innovative products. Technology is a supporting infrastructure in creative product development, and tolerance obtained through an environment that supports all forms of creativity.

Each product, including the creative industry products, has its product lifecycle. Some experts divide the PLC into four phases: introduction, growth stage, maturity stage and the stage of declining. Gecevska et al. (2010) states that PLCs management is required so that the products offered can be accepted by the consumer. Because this study aimed to dig up information about the product development roadmap which has been passed by batik fractal then it is a likely deepening of one or several parts of the PLC. 
Creative class is a group of people who create new and fresh ideas. Including in this group are scientists, engineers, professors, lecturers, poets and architects, as well as people who work in the field of design, education, art, music, and entertainment. They aim to create new ideas, new technologies, or creative content (Lazzeretti et al., 2009). Creativity can lead to the creation of new ideas not only for the people who are highly educated lived in urban areas but in the whole society in any area that has a skill/particular abilities and has a lateral and innovative mindset. Concerning space, many creative cities have grown by emphasising the contribution of the creative industries to economic growth and development of the city through cultural and artistic aspects. In his criticised concept of creative class, Pratt (2008) stated that the creative city is an attractive city, and, therefore, is inhabited by, creative class that works with hi-tech. According to Florida, $3 \mathrm{~T}$ is what causes the formation of creativity or creative city. This study, with a view of the order of occurrence, considers that the presence of the creative class who form a creative city. The argument is, Bandung recently gained recognition as a creative city after long known as a place of stay of the creative class

Anderson (2015) reviewing entrepreneurship as something relates to the process of change, value creation, and simultaneously also changing and creating individual. Having creative ideas to grow within the creative industries, there is a need for an entrepreneurial spirit and the ability to bring change to the next stage of product development.

There have been many instruments of government policies to support the creative industries, but the impact of its implementation on the creative industries varied. The types of policies are the existence of a public space, infrastructure and patents (Simatupang et al., 2008). Similarly, Sasongko and Anantadjaya (2014) expect government's commitment to push the development of the creative industry. As an example, policies that have been conducted by the Government of Bandung City in supporting the development of creative industries are: festival of creative industries, capital support to the SMEs in the creative industries, public areas and the presence of open spaces, media socialisation, scholarships, places and infrastructure.

Figure 1 Supporting factors of creative ideas

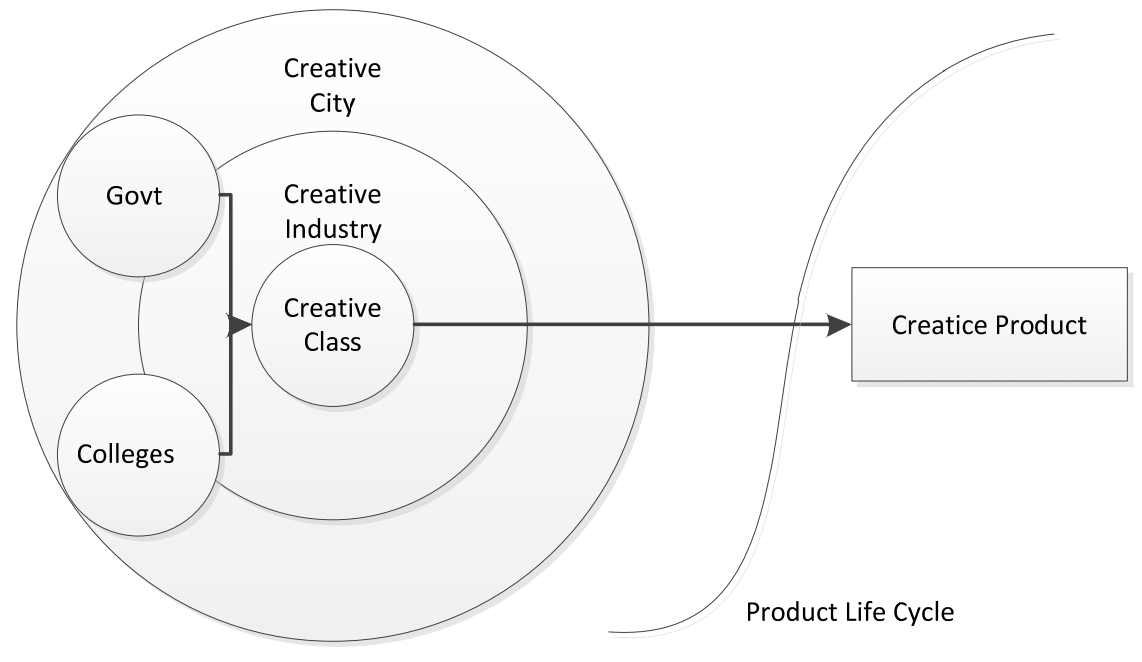


Proposition of this study stated that the colleges, as well as support from the government, promotes the existence of the creative class. This circumstance led to support creative ideas towards the establishment of creative industries located in the creative city. Additionally, entrepreneurship plays a significant role when the creative product makers began to introduce their products to the public. The combination of these factors allows the creation of the creative product in every stage of its development.

\section{Research method}

Key informants in this study were three founders of batik fractal. In-depth interviews were conducted on them separately to explore their experiences in managing batik fractal. Framework set up to examine the information are:

- The actors (people involved): The three founders and those who interact with them.

- Time (sequencing that takes place over time): When an event occurred.

- Place: Where the event occurred.

- Actions (things that people do): What has been done by participants and those who interact with them.

The following research design was established to structure the research steps.

Figure 2 Research design

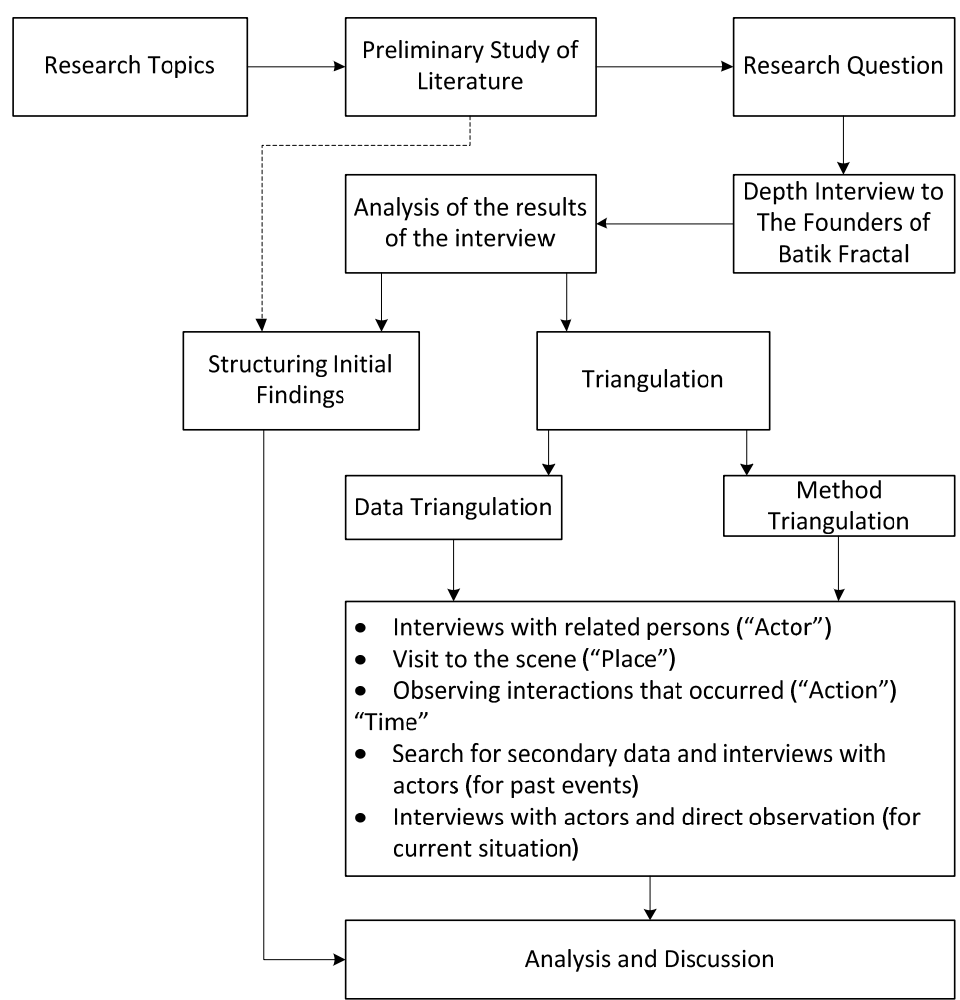


After having depth interviews with the founders of batik fractal and preliminary study of literature took place then the research continued to structuring the initial findings. This step was important since the information gathered need to be combined and arranged in order of its occurrence.

\section{Result and discussion}

The composition of the information obtained from the founders and literature reviews have indicated that there were stages of development of batik fractal. These stages were not the same as what was stated in theory PLC. There were two stages that passed before the stage of product introduction. The stages were early ideas and product research stages. Furthermore, the triangulation carried out on the information obtained in each stage. There was, at least, two major triangulation conducted at each stage. The triangulation was in the form of the people involved, where the event occurred, things that people did, and sequencing that takes place over time. Triangulation that carried out can be seen in Figure 3.

Figure 3 Triangulation at each stage of product development

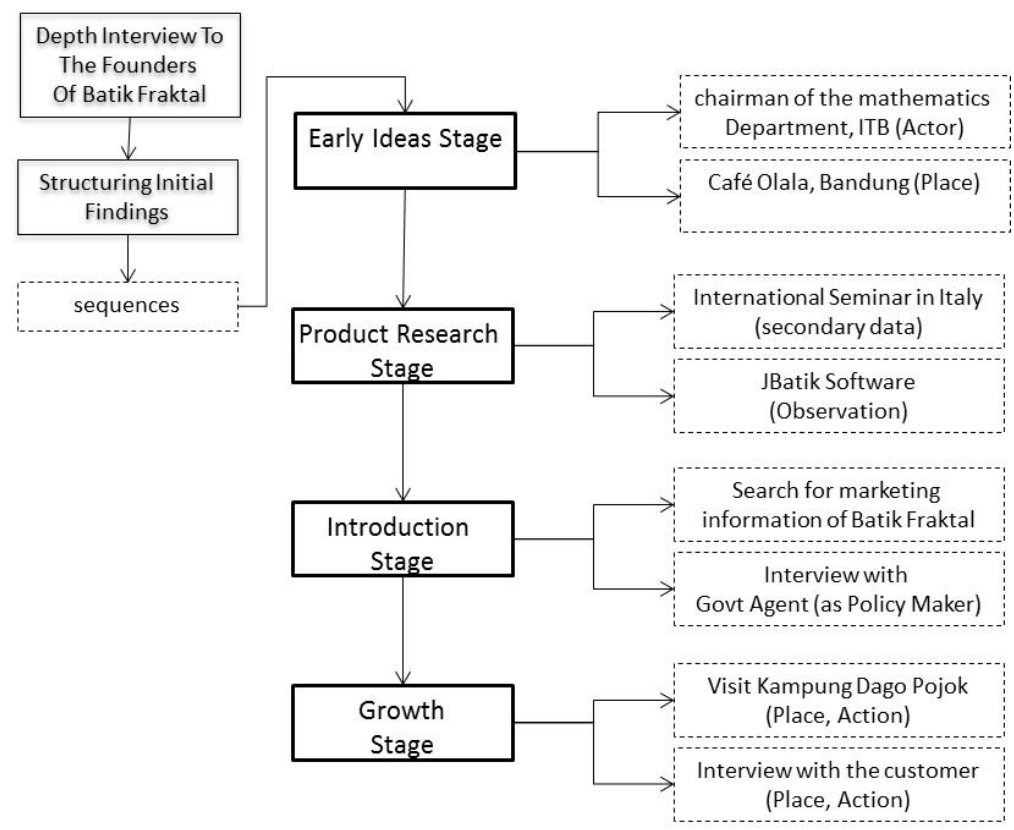

\subsection{Factors supporting transformation of creative ideas}

The characteristics of a city affect the existence of the creative industries because the city is a combination of creative talents and infrastructure (Turok, 2003). Like many other creative cities, Bandung City has many universities that produce graduates from various disciplines. This formal school graduates have the technical ability and creativity. In fact, the creative industries tend to congregate in urban and shape variations of the profession 
(Maskell and Lorenzen, 2004). On the other side, the graduates of these universities still have the challenge to develop skills in the form of soft skills, namely in the form of the ability to communicate, collaborate in teamwork and awareness to combine the skills and knowledge (Carr, 2009). Creative industry does usually grow in clusters for several reasons, namely:

1 historical factors and culture

2 agglomeration

3 related variety

4 the concentration of human capital

5 the creative class (Lazzeretti et al., 2009).

Creative ideas on batik fractal started by three founders Nancy, Lukman and Yun. They are part of the creative class of Bandung which come from different disciplines namely Science Communication, Architecture and Mathematics. Like many other creative ideas initiators, they often meet in public areas in Bandung City, which are the infrastructure of the establishment of creative industries. They have the awareness to combine their skills and knowledge to continue the creative idea to the next stage.

At the next stage, they use the technology (embodied in software development JBatik) and presenting its concept in an international seminar. Continuing to another factor which is the tolerance, the tolerance between all three as well as with other communities is very wide. The tolerance appears in the form of openness to talent, creativity and knowledge of a person or group of people.

Creative class, creative industries and creative city are factors that have not been adequate to bring creative ideas, which have been combined with technology, to get into the next phase of making the creative product. From the point of view of individual, creative ideas that have been combined with technology does not automatically transformed into products and accepted by society. It still needs the entrepreneurship to combine those factors in producing creative products (Audretsch and Keilbach, 2007). Entrepreneurship is a significant factor that must be possessed by entrepreneurs as they start their business because of the opportunities, or driven by, necessity, or a combination of both (Verheul et al., 2010).

When the founders at the stage of introduction of their products, they must had a driving factor, namely entrepreneurship. They found there was an opportunity to combine art, culture, creative ideas and technologies into a creative product that will be accepted by society. In addition to the opportunity, the motivation of the founders was also driven by necessity. They've invested their time and competence to conduct the research and introduced their ideas to the academic community. So, it was time to move forward.

The development of creative industries in the creative city that occurred in Indonesia is not only supported by academician but also by the community (Fahmi, 2014). The existence of a community in the form of creative industries not only supported by the strength of individuals but also the utilisation of government support that took place in Bandung (Simatupang et al., 2008). Thus, the creation of added value may become larger and reach the wider community (Margried, 2015).

At a further stage, the existence of batik fractal not only belongs to its founders but also involve the community. Batik Fractal Community is now a program created to generate public participation in the implementation of technology. The purpose of the 
existence of batik fractal becomes more widely into the community empowerment. Besides, the batik fractal was also successfully bridged the younger generation and the older generation to be in a creative activity that gives economic benefits to them.

\section{Conclusions}

Internal factors owned by the founders and other external factors support the success of batik fractal. From research conducted apparently at every stage of development that has been passed by the batik fractal, it appears that there was always a contributing factor that supports its success.

At early ideas stage, the presence of higher education institution becomes an important factor the emergence of the creative class, which bring creative ideas to evolve into innovative products. Moreover, the existence of public open space also supports the exchange of creative ideas of talented young people.

At product research stage, the technology, talent, tolerance (3T) determinants started by Florida joined to form the initial models of batik fractal. The making of JBatik software as well as the founders' participation in the seminar to introduce creative ideas is a proof of concept implementation of $3 \mathrm{~T}$.

At introduction stage, networking becomes the most important element in introducing creative industry products to the public. Also, the entrepreneurial spirit is also necessary to unite all the factors of production and manage the risks of potential failures that may occur. Besides, support from the government is also needed, especially in introducing product and brand of creative product to the market.

At growth stage, the production process is no longer carried out individually but by the empowerment of the community. Through this collaboration not only the community becomes more empowered and earn income but also, there is a strengthening the creative products brand.

If the government in developing countries build the infrastructures, such as facilitating the initiation of creative industries formed by talented young people, then there will be many opportunities for them to transform creative ideas into creative products. Finally, the society and the economy will receive the benefits of this creative product development.

\section{Acknowledgements}

The author sincerely thanks the reviewer for constructive criticisms and valuable comments, which were of great help in revising the manuscript. The author is grateful to Mrs. Yani Adriani from Tourism Planning and Development Center, Bandung Institute of Technology, for her inputs on this manuscript. Also, the author appreciates Yandra Alfiansyah for his tireless work to collect data and information that is very useful in the analysis of this study. Finally, the author much obliged for the founders batik fractal, Mrs. Nancy Margried, Mr. Yun Hariadi, and Mr. Muhammad Lukman on their willingness to disclose valuable information about batik fractal. 


\section{References}

Anderson, A.R. (2015) 'Conceptualising entrepreneurship as economic 'explanation' and the consequent loss of 'understanding.', International J. Business and Globalization, Vol. 14, No. 2, pp.145-157.

Audretsch, D.B. and Keilbach, M. (2007) 'The theory of knowledge spillover entrepreneurship', Journal of Management Studies, Vol. 44, No. 7, pp.1242-1254 [online] http://doi.wiley.com/ 10.1111/j.1467-6486.2007.00722.x (accessed 5 October 2015).

Bayliss, D. (2007) 'The rise of the creative city: culture and creativity in Copenhagen', European Planning Studies, Vol. 15, No. 7, pp.889-903 [online] http://www.tandfonline.com/doi/full/ 10.1080/09654310701356183 (accessed 7 October 2015).

Carr, J. (2009) Creative Industries, Creative Workers and the Creative Economy: A Review of Selected Recent Literature, pp.1-29, Scottish Government Social Research.

Fahmi, F.Z. (2014) 'Creative economy policy in developing countries: the case of Indonesia', Conference Proceeding at ERSA 54th Congress, Saint Petersburg, Russia.

Florida, R. (2003) 'Cities and the creative class', City and Community, March, Vol. 2, pp.3-19 [online] http://onlinelibrary.wiley.com/doi/10.1111/1540-6040.00034 (accessed 23 December 2015).

Gecevska, V., Chiabert, P., Anisic, Z., Lombard, F. and Cus, F. (2010) 'Product lifecycle management through innovative and competitive business environment', Journal of Industrial Engineering and Management, Vol. 3, No. 2, pp.323-336.

Lazzeretti, L., Boix, R. and Capone, F. (2009) 'Why do creative industries cluster? An analysis of the determinants of clustering of creative industries', DRUID Summer Conference, pp.1-34 [online] http://www2.druid.dk/conferences/viewpaper.php?id=5746\&cf $=32$ (accessed 14 November 2015).

Margried, N. (2015) 'Batik Fractal community: creative engagement through technology', Procedia - Social and Behavioral Sciences, Vol. 184, pp.214-222.

Maskell, P. and Lorenzen, M. (2004) 'The cluster as market organisation', Urban Studies, Vol. 41, Nos. 5/6, pp.991-1009, Routledge [online] http://usj.sagepub.com/cgi/doi/10.1080/ 00420980410001675878 (accessed 12 October 2015).

Melnikas, B. (2010) 'Sustainable development and creation of the knowledge economy: the new theoretical approach', Technological and Economic Development of Economy, Vol. 16, No. 3, pp.516-540 [online] http://www.tandfonline.com/doi/abs/10.3846/tede.2010.32 (accessed 25 November 2015).

Pratt, A.C. (2008) 'Creative cities: the cultural industries and the creative class', Geografiska Annaler, Series B: Human Geography, Vol. 90, No. 2, pp.107-117 [online] http://doi.wiley. com/10.1111/j.1468-0467.2008.00281.x (accessed 14 November 2015).

Sasongko, I.A. and Anantadjaya, S.P.D. (2014) 'Strategic intention and financial support on MSMEs: an investigative study in Indonesian creative industry', Review of Integrative Business and Economics Research, Vol. 3, No. 1, pp.114-129.

Simatupang, T.M. et al. (2008) 'Analisis Kebijakan Pengembangan Industri Kreatif di Kota Bandung', Jurnal Manajemen Teknologi ITB, Vol. 8, No. 1, pp.1-12.

Turok, I. (2003) 'Cities, clusters and creative industries: the case of film and television in Scotland', European Planning Studies, Vol. 11, No. 5, pp.549-565 [online] http://doi.org/10.1080/09654310303652 (accessed 28 December 2015).

UNESCO Press (2015) 47 Cities Join the UNESCO Creative Cities Network [online] http://www.unesco.org/new/en/media-services/single-view/news/47 cities join the unesco_creative_cities_network/\#.VoCfR_mLTIU (accessed 12 December 2015).

Verheul, I., Thurik, R., Hessels, J. and van der Zwan, P. (2010) Factors Influencing the Entrepreneurial Engagement of Opportunity and Necessity Entrepreneurs, EIM Research Reports, March, H201011, pp.1-24. 